\title{
Plasticity of N:P ratios in laboratory and field populations of Trichodesmium spp.
}

\author{
Jamie M. Krauk ${ }^{1,5}$, Tracy A. Villareal ${ }^{2}$, Jill A. Sohm ${ }^{3}$, Joseph P. Montoya ${ }^{4}$, \\ Douglas G. Capone ${ }^{3, *}$ \\ ${ }^{1}$ Chesapeake Biological Laboratory, University of Maryland Center for Environmental Sciences, Solomons, \\ Maryland 20615, USA \\ ${ }^{2}$ Marine Science Institute, The University of Texas at Austin, 750 Channel View Dr., Port Aransas, Texas 78373, USA \\ ${ }^{3}$ Wrigley Institute for Environmental Studies and Department of Biological Sciences University of Southern California, \\ Los Angeles, California 90089, USA \\ ${ }^{4}$ School of Biology, Georgia Institute of Technology, Atlanta, Georgia 30332, USA
}

${ }^{5}$ Present address: National Sea Grant Office, Department of Commerce, National Oceanic and Atmospheric Administration, 1315 East West Highway, R/SG, SSMC 3 room 11853, Silver Spring, Maryland 20910, USA

\begin{abstract}
We followed changes in N:P ratios in batch cultures of the planktonic marine cyanobacterium Trichodesmium (IMS 101) grown in 2 different media and in field populations from 4 different oceanic regions. Cultures grown on low P media showed a rapid rise in N:P ratio upon depletion of phosphate. Ratios exceeding 125 were reached in 1 experiment before attaining stationary phase. A transect across the North Atlantic Ocean along $32^{\circ} \mathrm{N}$ showed a monotonic decrease in the N:P ratio of field collected colonies, dropping from about 60:1 on the western side of the basin to about 30:1 on the eastern side. A second cruise sampled colonies and surface slicks in waters along the north coast of Australia, where ratios of $\mathrm{N}: \mathrm{P}$ were generally lower than in the North Atlantic, ranging from 11:1 to $47: 1$ with an average of 22:1. A comparison of rising and sinking colonies collected at 8 stations in the Gulf of Mexico shows a higher mean N:P ratio among sinking colonies than floating colonies. Overall, the average N:P in the Gulf of Mexico was about 68:1. N:P ratios of Trichodesmium around the Hawaiian Islands were very consistent between 2 consecutive years of sampling, with an average colony N:P for both years of about 38:1. Our research demonstrates high variability in the cellular N:P in Trichodesmium both in the laboratory and in the field. Trichodesmium N:P ratio may provide an index to the relative severity of P limitation in these diazotrophs. Geochemical and ecological modeling efforts which rely on using the N:P ratio of diazotrophs in deriving nitrogen fixation rates should account for the variability of these ratios in situ.
\end{abstract}

KEY WORDS: Trichodesmium $\cdot$ N:P ratio $\cdot$ Nitrogen fixation · Diazotroph $\cdot$ Cyanobacteria Resale or republication not permitted without written consent of the publisher

\section{INTRODUCTION}

Trichodesmium spp. is a colonial marine cyanobacterium that is widely distributed throughout the tropics and subtropics in oligotrophic waters (Capone et al. 1997, Karl et al. 2002, Carpenter et al. 2004). It is a notable for its ability to fix atmospheric dinitrogen (Capone et al. 2005). While major advances have been made in understanding the biology and spatial distribution of Trichodesmium, many questions remain regarding its elemental composition and stoichiometry of growth (Mulholland \& Capone 2001). Letelier \& Karl (1996) reported that the particulate organic carbon to particulate organic nitrogen (POC:PON) ratio of Trichodesmium is close to the Redfield value (6.3:1) but that the PON to particulate organic phosphorus (PON:POP, hereafter biomass N:P) ratios of around 42 (colonies) to 52 (free trichomes) are substantially higher than the Redfield value (i.e. 16:1). While these results are consistent with earlier studies in the Pacific by Mague (1977) and Karl et al. (1992), the relative plasticity of these cellular ratios with respect to geo- 
graphical location and physiology are not known. Comparative analyses of laboratory populations of Trichodesmium and other diazotrophs under different growth conditions and of diverse field populations are necessary to understand the potential variance in this key cellular parameter. In addition, constraining diazotroph biomass N:P ratios is important for improving geochemical estimates of nitrogen fixation in the ocean.

Several recent geochemical studies of nitrate and phosphate fields in sub-euphotic zone waters of the tropical and subtropical North Atlantic have reported large excesses of regenerated nitrate $\left(\mathrm{NO}_{3}{ }^{-}\right)$relative to phosphate $\left(\mathrm{PO}_{4}{ }^{3-}\right)$. A parameter, termed $N^{*}$, first developed by Michaels et al. (1996) and more fully by Gruber \& Sarmiento (1997), was applied to data from the Geochemical Ocean Section Study (GEOSEC) cruises from 1972 to $1978 . N^{*}$ represents the degree to which $\mathrm{NO}_{3}^{-}$concentration deviates from Redfield proportions with $\mathrm{PO}_{4}{ }^{3-}$ concentration and is generally some variant of:

$$
N^{*}=\left[\mathrm{NO}_{3}{ }^{-}\right]-16 \times\left[\mathrm{PO}_{4}{ }^{3-}\right]
$$

Positive gradients of $N^{*}$ indicate possible exogenous sources of nitrogen (e.g. $\mathrm{N}_{2}$ fixation) or removal of phosphorus while gradients of decreasing $N^{*}$ indicate differential removal of nitrogen (e.g. by denitrification) relative to $P$.

In the Atlantic, there is a distinct $N^{*}$ maximum in the thermocline of the tropical and subtropical North Atlantic, with higher values in the northern gyre than in the southern gyre. These anomalies have been interpreted to result from $\mathrm{N}_{2}$ fixation (Michaels et al. 1996, Gruber \& Sarmiento 1997). Gruber \& Sarmiento (1997) estimated total $\mathrm{N}_{2}$ fixation by integrating the excess $\mathrm{N}$ signal along isopycnal surfaces and assuming that the biomass N:P ratio of $\mathrm{N}_{2}$ fixers was greater than Redfield (16:1). They found the rates derived by this approach to be substantially greater than earlier estimated (e.g. Carpenter 1983a). However, basin scale gradients are not well characterized and use of regional gradients may yield lower integrated rates than previously suggested (Hansell et al. 2004). While Gruber \& Sarmiento (1997) and Hansell et al. (2004) differ in their assumptions about the size and magnitude of these gradients, they both assume an N:P ratio for $\mathrm{N}_{2}$ fixers of 125:1. However, the derived estimate of $\mathrm{N}_{2}$ fixation is sensitive to the $\mathrm{N}: \mathrm{P}$ chosen, and as the $\mathrm{N}: \mathrm{P}$ ratio of diazotrophs is decreased, the estimate of $\mathrm{N}_{2}$ fixation rate increases.

Using the N:P ratio of field and laboratory populations of Trichodesmium as a diagnostic marker, it may be possible to assess the relative extent of $\mathrm{P}$ limitation in the ocean and also to contribute essential data to the wider questions of interpreting the $N^{*}$ signal and of the role of oligotrophic oceans in global $\mathrm{N}_{2}$ fixation. We therefore examined the response of the biomass $\mathrm{N}: \mathrm{P}$ ratio of cultures of Trichodesmium grown under different initial phosphate concentrations and determined the N:P ratio of natural populations of Trichodesmium at 4 diverse oceanic locations.

\section{MATERIALS AND METHODS}

Culture growth curve experiments. We examined Trichodesmium IMS 101 in batch culture in order to determine the variability in their biomass N:P ratios. The cultures were maintained in the laboratory statically in an incubator with cool white fluorescent bulbs (irradiance $=90 \mu \mathrm{mol}$ quanta $\mathrm{m}^{-2} \mathrm{~s}^{-1}$ ) on a $12: 12 \mathrm{~h}$ light:dark cycle at $27^{\circ} \mathrm{C}$. All cultures were grown on YBC II media, a defined nitrogen free media of salinity 36 PSU (Chen et al. 1996), shaken once per day, and transferred on average once every 2 to $3 \mathrm{wk}$ when densities increased or culture health declined. We here report the results from 2 growth curve experiments which were each conducted for a duration of approximately 1 mo.

The first growth curve experiment (Expt 1) ran from 7 May to 1 June 1999, and was carried out in duplicate under 2 different conditions. Media 1 was standard YBC II media (Chen et al. 1996), containing $50 \mu \mathrm{M} \mathrm{PO}_{4}{ }^{3-}$ and here termed 'high phosphate'. Media 2 was the same except it contained only $5 \mu \mathrm{M}$ $\mathrm{PO}_{4}{ }^{3-}$ ('low phosphate'). Inocula for both treatments (low and high phosphate) were raised in standard YBC II with $50 \mu \mathrm{M}$ phosphate. Samples were taken from each treatment flask every other day for $25 \mathrm{~d}$. At each time point, $5 \mathrm{ml}$ of culture was preserved in $2 \%$ glutaraldehyde for later trichome counts using light microscopy. We assumed 100 cells per trichome (Carpenter 1983a). Sub-samples were also collected for $\mathrm{N}_{2}$ fixation determination and for filtration onto combusted $25 \mathrm{~mm}$ GF/F filters for PON, POC and POP determinations. The volume sampled was adjusted throughout the growth curve to accommodate increasing cell density. POP analysis was conducted by the Nutrient Analytical Services Laboratory (NASL) at the Chesapeake Biological Laboratory (CBL) using the persulfate digestion method of D'Elia et al. (1977) and total particulate C and N was measured on an elemental analyzer (Europa ANCA CN) interfaced to a mass spectrometer (Europa 20/20) using the integrated mass signal for each element. Ten $\mathrm{ml}$ samples were filtered onto $5 \mu \mathrm{m}$ polycarbonate membrane filters and analyzed for chlorophyll content using a methanol extraction and subsequent measurement of chlorophyll by fluorescence, as described by MacKinney (1941). 
A second growth curve (Expt 2) similar in design and culture conditions to Expt 1 was performed in triplicate at the University of Southern California from 11 February 2000 through 3 March 2000. In Expt 2, parent cultures for inocula had been raised under the 2 respective conditions of low and high phosphate. In addition to the standard suite of parameters, concentrations of $\mathrm{PO}_{4}{ }^{3-}$ were also analyzed over the course of this experiment on a Lachat continuous flow injection colorimetric nutrient analyzer. POP and PON contents were measured as $\mathrm{PO}_{4}{ }^{3-}$ and $\mathrm{NO}_{3}{ }^{-}$after potassium persulfate digestion similar to the method used in Expt 1 (Raimbault et al. 1999) and also analyzed on the Lachat. In all cases, bacteria were present in the culture under both media conditions at low $\left(<10^{4} \mathrm{ml}^{-1}\right)$ initial densities but reached densities of $10^{6} \mathrm{ml}^{-1}$ by stationary phase. N:P ratios are expressed as molar ratios.

The acetylene reduction procedure was used to estimate $\mathrm{N}_{2}$ fixation rate (Capone 1993). Ten ml volumes of culture in serum vials sealed with silicone septa were amended with $1 \mathrm{ml}$ of purified acetylene Samples were incubated at $27^{\circ} \mathrm{C}$. Sub-samples $(100 \mu l)$ of the gas phase were removed and analyzed by flame ionization gas chromatography about every $30 \mathrm{~min}$ over a time course of several hours as described by Capone (1993). Assays were conducted at every time point along the growth curve and were initiated at approximately the same time in the late morning or early afternoon every day, with light incubation at $27^{\circ} \mathrm{C} . \mathrm{N}_{2}$ fixation was not measured during dark periods.

Field collections. Field collections were made during cruises aboard the RV 'Maurice Ewing' (27 October through 29 November 1999) in tropical northern Australian waters (primarily the Arafura, Timor and Coral Seas); aboard the RV 'Seward Johnson' in the Sargasso Sea and Atlantic Ocean on a cruise track from Bermuda to Tenerife, Canary Islands (9 May through 24 May 2000); aboard the RV 'Longhorn' in the Gulf of Mexico (July 2000); and aboard the RV 'Kilo Moana' (September to October 2002) and the RV 'Roger Revelle' (July to August 2003) in the North Pacific Subtropical Gyre (NPSG) (Fig. 1).

During the November 1999 cruise north of Australia, fresh samples of Trichodesmium spp. were generally collected by gentle plankton tows from the upper $20 \mathrm{~m}$ of the water column. In cases where Trichodesmium was extremely abundant and could be seen in patches or 'slicks' on the surface of the water, samples were collected by dropping a plastic bucket directly over the side of the ship. Some 'slick' samples were also collected by deploying a Zodiac from the ship and bucket sampling directly off the side. Only colonies were collected by hand picking them with disposable plastic inoculating loops into filtered seawater (GF/F) stored in polycarbonate bottles for filtering.

Samples of colonies were filtered onto precombusted GF/F filters. Particulate filters were kept frozen during the cruise and then dried in a $60^{\circ} \mathrm{C}$ drying oven at the
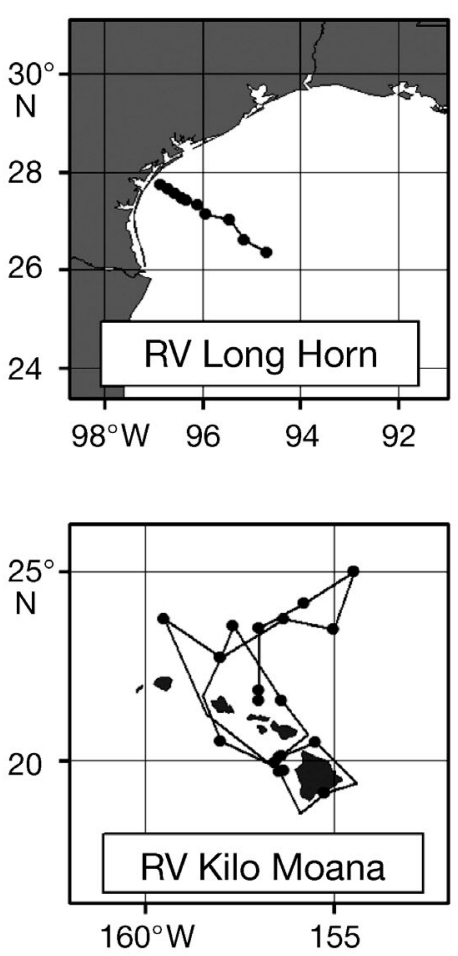
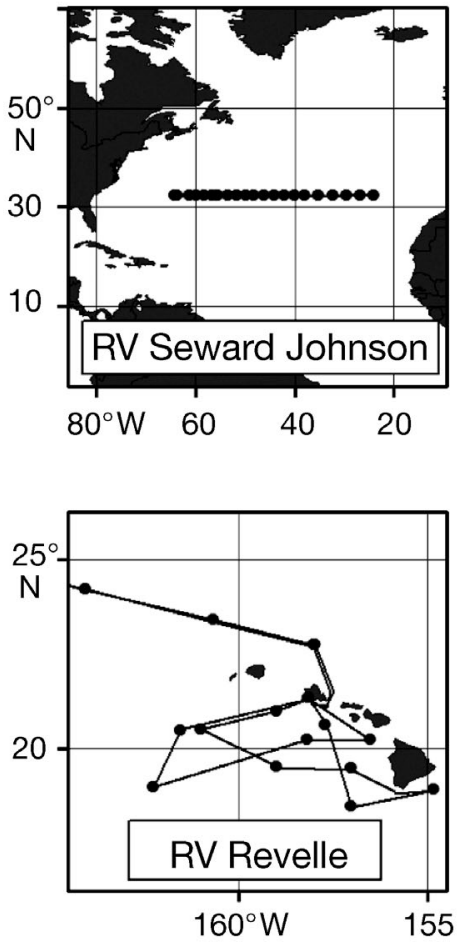

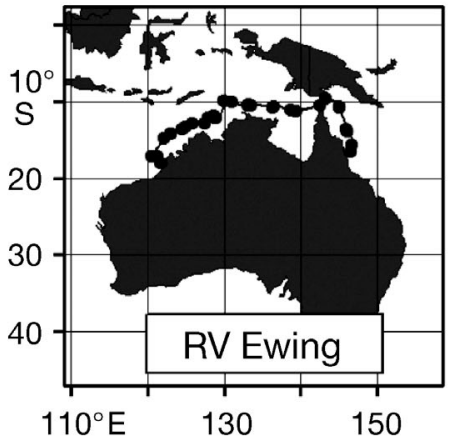

Fig. 1. Trichodesmium spp. Cruise tracks for $\mathrm{N}: \mathrm{P}$ ratio field conditions 
termination of the cruise for later persulfate digestion (Raimbault et al. 1999) and analysis on a Lachat continuous-flow auto analyzer system at the Marine Science Institute (University of Texas at Austin). Similar collections were undertaken in the Sargasso Sea and Atlantic Ocean. In the Gulf of Mexico, Trichodesmium brought aboard were separated on the basis of buoyancy status (floating or sinking) and these groups were analyzed for particulate matter separately (Villareal \& Carpenter 2003). On the first NPSG cruise, colonies of Trichodesmium were picked out of the plankton tow using a plastic inoculating loop while filaments of the closely related Katygnemene spp. were allowed to aggregate on the surface of the tow material held in a bucket, then gently removed and placed in freshly $\mathrm{GF} / \mathrm{F}$ filtered seawater. Both types of samples were poured into the barrel of a syringe and then gently filtered onto an in line GF/F filter. On the 2003 NPSG cruise, Trichodesmium colonies were picked directly onto filters with an inoculating loop after rinsing in filtered seawater. In all environments, both puff and tuft colony morphologies were collected.

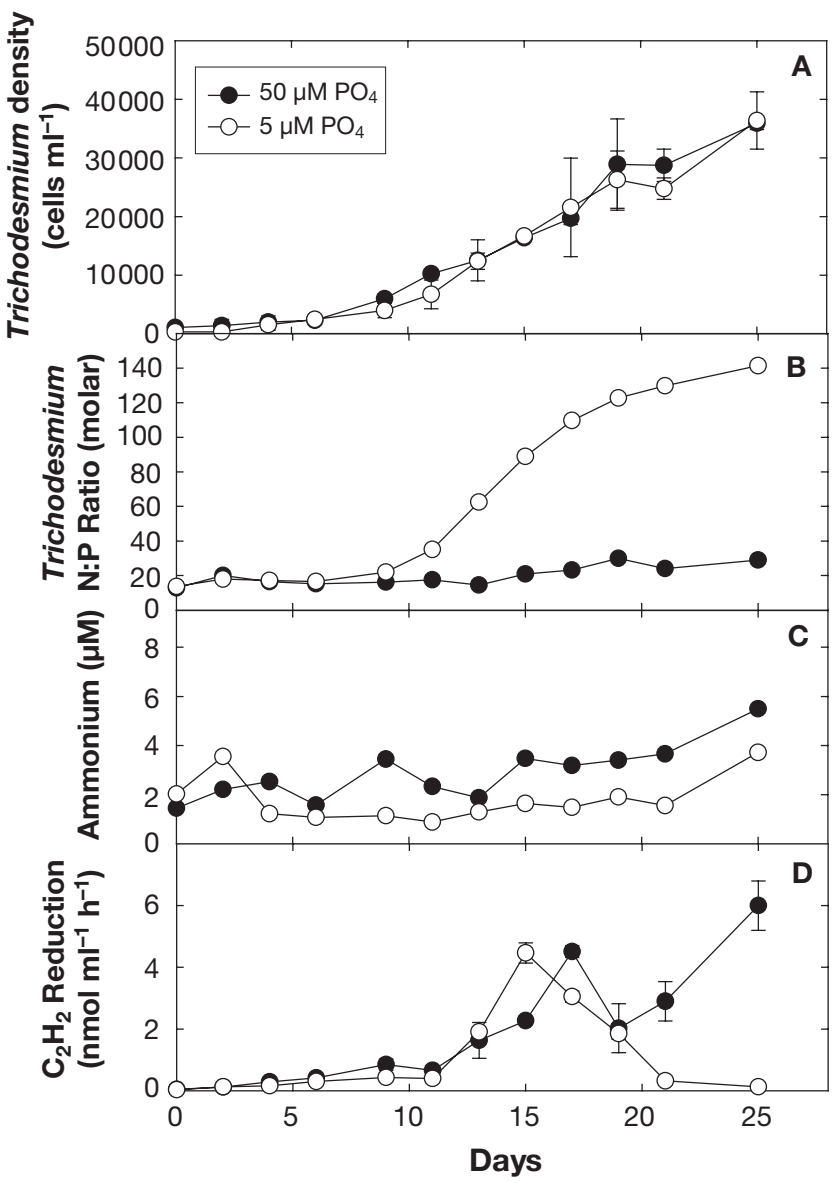

Fig. 2. Trichodesmium IMS 101 growth curve 1. (A) Cell counts, (B) N:P ratio, (C) ammonium concentrations and (D) $\mathrm{C}_{2} \mathrm{H}_{2}$ reduction rates. Error bars are $\pm \mathrm{SE}$

\section{RESULTS}

\section{Culture growth experiments}

During the 25 d Expt 1, cultures grown on each media followed very similar trends, with $6 \mathrm{~d}$ lags followed by rapid growth. Biomass doubling times were $3.5 \mathrm{~d}$ for the high phosphate culture and $3.4 \mathrm{~d}$ for the low phosphate culture, with density finally reaching $>30000$ cells ml $^{-1}$ by Day 25 (Fig. 2).

In Expt 2, the culture grown in high phosphate media reached only 23000 cells ml ${ }^{-1}$ at Day 18 , maintaining a $2.3 \mathrm{~d}$ doubling time throughout before leveling off; the culture grown in low phosphate media exhibited a doubling time of $2.5 \mathrm{~d}$ and peaked at 10000 cell ml ${ }^{-1}$ at Day 14 followed by a sharp decline to 10 cells ml $^{-1}$ by the end of the growth curve at Day 21 (Fig. 3). For both culture experiments, doubling

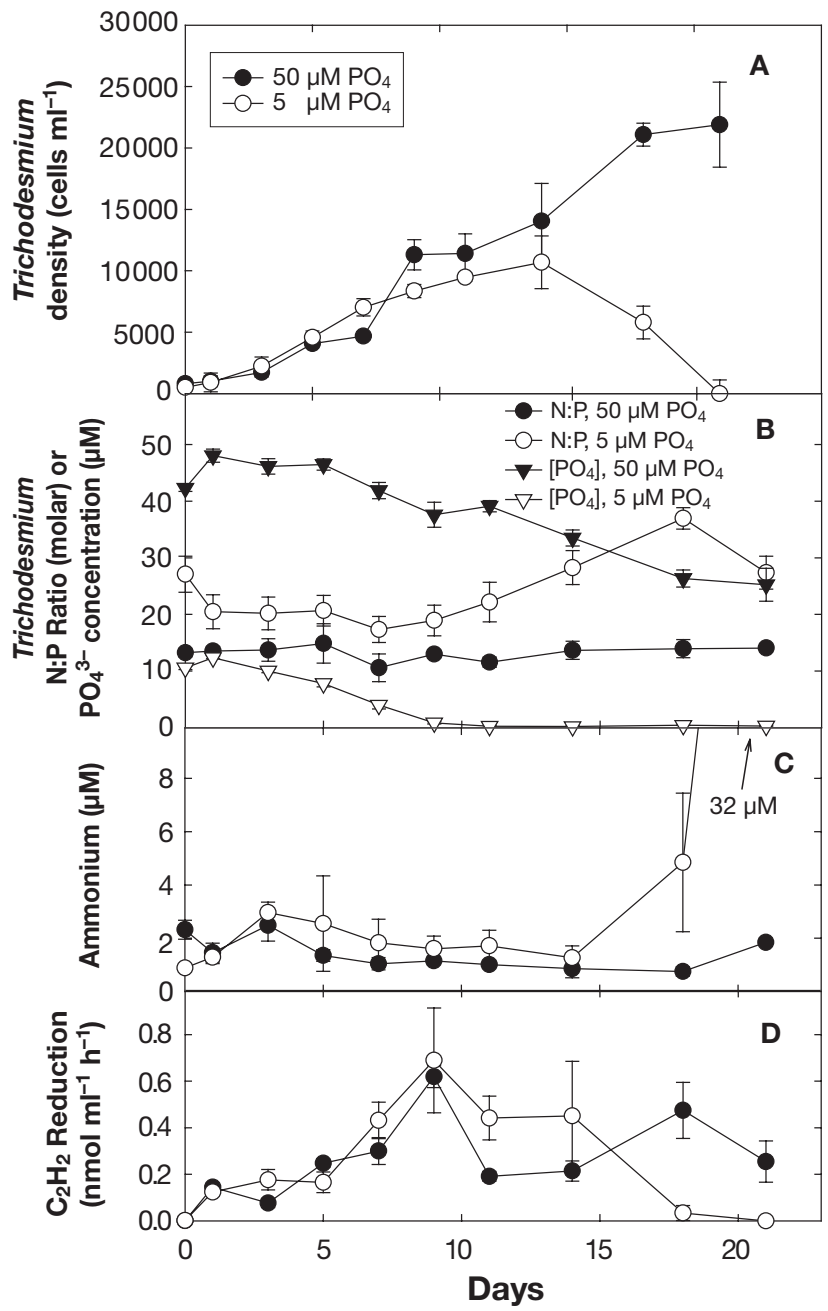

Fig. 3. Trichodesmium IMS 101 growth curve 2. (A) Cell counts, (B) $\mathrm{N}: \mathrm{P}$ ratio and $\mathrm{PO}_{4}{ }^{3-}$ concentrations, (C) ammonium concentrations and (D) $\mathrm{C}_{2} \mathrm{H}_{2}$ reduction rates. Error bars are $\pm \mathrm{SE}$ 
times of 2 to $4 \mathrm{~d}$ were similar to growth rates reported by Chen et al. (1996) and Mulholland \& Capone (1999, 2001).

Chlorophyll a trends closely mirrored cell counts with chlorophyll levels in low phosphate media cultures declining during the last days of the growth curve (Mulholland \& Capone 1999), while chlorophyll levels in standard YBC II media with high phosphate continued to increase or level off during the final days of the growth curve (data not shown). Ambient $\mathrm{NH}_{4}^{+}$ concentrations in culture filtrates were measured in each of the 2 growth curves during Expts 1 and 2, and typically fluctuated between 1 and $4 \mu \mathrm{M}$ over the duration of the growth curve (Figs. $2 \mathrm{C} \& 3 \mathrm{C}$ ). The ammonium levels for the 2 experiments increased during the last time point as the cultures reached stationary phase, with a sharp increase at the final point in the low phosphate treatment of Expt 2. $\mathrm{N}_{2}$ fixation in the 2 cultures was comparable over most of the time course, except for the final 2 time points when rates in the $\mathrm{P}$ depleted cultures fell to low levels while being maintained in the high P media (Figs. 2D \& 3D).

Ambient phosphate was measured in the filtrate only during Expt 2 and was initially approximately equivalent to the $50 \mu \mathrm{M}$ high phosphate media conditions in the high $\mathrm{P}$ treatment and about $10 \mathrm{\mu M} \mathrm{PO}_{4}{ }^{3-}$ in the low phosphate media (Fig. 3B). The somewhat higher concentration than expected $(5 \mu \mathrm{M})$ in the low $\mathrm{PO}_{4}{ }^{3-}$ treatment may have been due to a minor contamination artifact or analytical error. Phosphate concentrations decreased from 48 to $25 \mu \mathrm{M}$ in the standard YBC II media-grown culture and from an initial concentration of 10 to $0 \mu \mathrm{M}$ on Day 11 in the low phosphate media when the N:P ratio began to increase (Fig. 3B).

The biomass N:P ratios of cultures grown in high phosphate YBC II were near or below the Redfield ratio of 16:1 (Figs. 2B \& 3B) and ranged from 7 to 18 in a preliminary experiment (data not shown), 8 to 11 during Expt 1 and 11 to 15 during Expt 2. However, cultures grown on $5 \mu \mathrm{M} \mathrm{KH}_{2} \mathrm{PO}_{4}$ media, while initially near Redfield $\mathrm{N}: \mathrm{P}$, generally increased their biomass $\mathrm{N}$ :P ratio as the growth curve progressed. The biomass $\mathrm{N}: \mathrm{P}$ of low phosphate media-grown culture increased from 8 to 140 in Expt 1 and from 13 to 37 during Expt 2.

A 2-factor ANOVA and mixed model design was performed on each full data set of each growth curve and tested against the theoretical Redfield ratio of 106 C:16 N:1 P. Cultures grown with high and low phosphate availability in Expts 1 and 2 both had N:P ratios significantly different than Redfield $(p<0.05)$. The mixed model statistic showed that cultures grown on high phosphate during Expts 1 and 2 had biomass N:P ratios significantly lower than 16 and cultures grown on low phosphate in both experiments had ratios significantly higher than 16 ( $\mathrm{p}<0.05$ ). In Expt 2 , the off- set in the biomass N:P ratio between high and low phosphate cultures initially and across the growth curve was significantly different ( $p<0.05)$ (see above). Ambient phosphate in the filtrate of low phosphate cultures decreased in parallel with the sharp increase in biomass $\mathrm{N}: \mathrm{P}$, while the high phosphate cultures showed only a slight decrease in ambient phosphate as phosphorus was incorporated into biomass. Expt 2 also showed a sharp decrease in trichome density and chlorophyll a content in low phosphate cultures at the same time that $\mathrm{PO}_{4}{ }^{3-}$ was depleted from the media.

A simple phosphorus mass balance of Expt 2, with both POP in Trichodesmium and ambient $\mathrm{PO}_{4}{ }^{3-}$ in filtrate, showed that at least $77 \%$ of the $50 \mu \mathrm{M}$ initial $\mathrm{PO}_{4}{ }^{3-}$ from YBC II media was accounted for by POP and at least $65 \%$ of the $5 \mu \mathrm{M}$ initial $\mathrm{PO}_{4}{ }^{3-}$ from the low phosphate media was recovered as POP. The remainder was likely in the unmeasured dissolved organic phosphorus (DOP) pool, or alternatively a result of incomplete digestion of POP (or both).

\section{Field collections}

The field populations sampled represented a range of conditions and densities of Trichodesmium. During the Australian cruise of October to November 1999, Trichodesmium spp. was abundant and highly variable, and surface slicks were observed at many stations throughout the cruises, reaching densities over $10^{5}$ colonies $^{-1}$ (Mulholland et al. 2002). The Atlantic cruise occurred in May 2000, relatively early for high densities of Trichodesmium in this region (McCarthy \& Carpenter 1979). Densities were less than 0.05 colony $^{-1}$ at every station along the cruise track at $32^{\circ} \mathrm{N}$ latitude with the exception of Stn 43 , where densities were 2 colonies $^{-1}$. Colony densities in the Gulf of Mexico were 2 to 5 colonies $^{-1}$ at most stations with 1 station showing a surface slick of 51 colonies $^{-1}$. Densities of colonies on both the September 2002 and the August 2003 Pacific cruises ranged from less than 1 to up to 12 colonies $^{-1}$ with an average of about 2 colonies $^{-1}$.

Ambient nutrient concentration varied greatly across the Australian transect. Surface $\mathrm{NO}_{\mathrm{x}}\left(\mathrm{NO}_{2}\right.$ plus $\left.\mathrm{NO}_{3}\right)$ values ranged from 0 to $2.2 \mu \mathrm{M}$ across stations while $\mathrm{PO}_{4}{ }^{3-}$ values varied from 0 to $0.3 \mu \mathrm{M}$. At most stations, the ratio of $\mathrm{NO}_{\mathrm{x}}: \mathrm{PO}_{4}{ }^{3-}$ was well below 16:1, averaging about 3.9. Surface nutrient concentrations of $\mathrm{NO}_{\mathrm{x}}$ and $\mathrm{PO}_{4}{ }^{3-}$ were below the detection limit in the North Atlantic. In the Gulf of Mexico, $\mathrm{PO}_{4}{ }^{3-}$ values were very low $(\sim 0.03 \mu \mathrm{M})$ to unmeasurable, while $\mathrm{NO}_{\mathrm{x}}$ was detected at most stations in the 0.02 to $0.08 \mu \mathrm{M}$ range. Surface values for $\mathrm{NO}_{3}{ }^{-}$were generally below the limit of detection for the 2 North Pacific cruises, while $\mathrm{PO}_{4}{ }^{3-}$ 

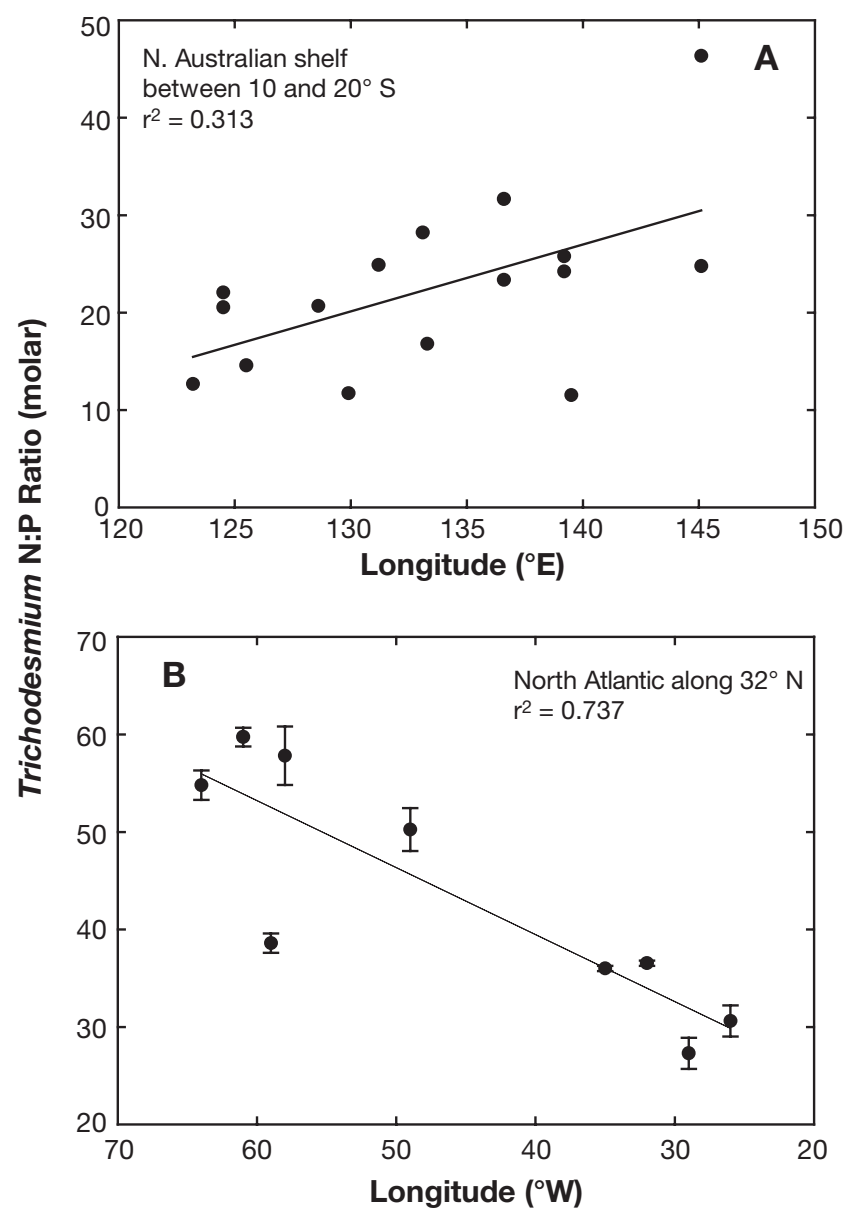

Fig. 4. Trichodesmium spp. N:P ratios of field populations Samples were performed in duplicate for (A) the Australian transect and in triplicate for (B) the North Atlantic transect.

Values in (B) are \pm SE. Note differences in $y$-axis scale

concentrations during the September 2002 cruise averaged about $0.03 \mu \mathrm{M}$ and ranged from 0.005 to $0.108 \mu \mathrm{M}$ on the August 2003 cruise.

The N:P ratio along a 2-way transit of northern Australia (Fig. 4A) ranged from about 11 to 47, with an average of 22. There was a weak trend of decreasing $\mathrm{N}: \mathrm{P}$ toward the west. There was no apparent relationship between the N:P ratio of Trichodesmium and surface $\mathrm{PO}_{4}{ }^{3-}$ concentration $\left(\mathrm{r}^{2}=0.005\right)$. A decreasing trend in the PON:POP ratio in Trichodesmium spp. colonies was readily apparent across the west to east Atlantic transect along $32^{\circ} \mathrm{N}$ (Fig. 4B), with highest values of Trichodesmium N:P of 60 at the western extreme, and much lower values of about 30 at the eastern end of the transect.

In the Gulf of Mexico, the biomass N:P of floating colonies ranged from 27.7 to 69.7 , with an average of approximately 50. A frequency histogram of colony $\mathrm{N}: \mathrm{P}$ showed substantial variation within the buoyancy category. Mean biomass N:P ratio varied more widely

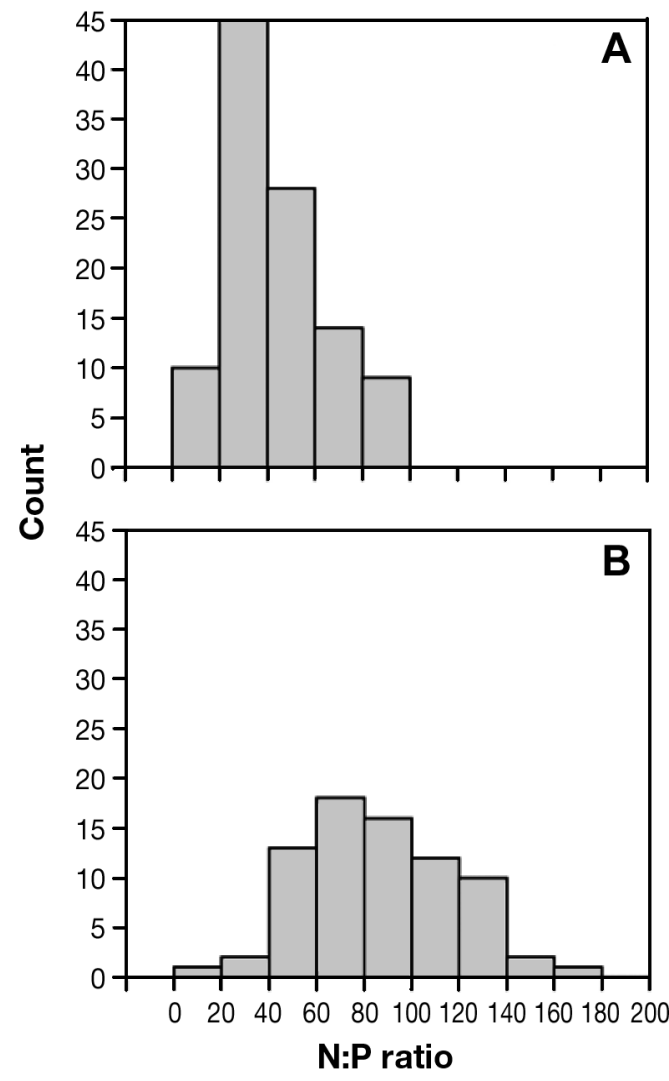

Fig. 5. Trichodesmium spp.. N:P ratios of (A) floating and (B) sinking colonies (Gulf of Mexico)

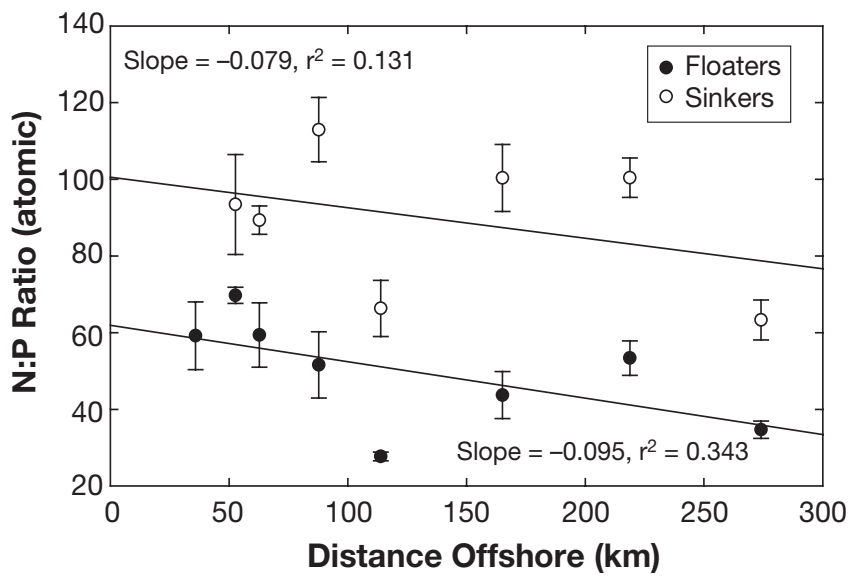

Fig. 6. Trichodesmium spp.. N:P ratios of floating and sinking colonies (Gulf of Mexico). Averages for each station $\pm \mathrm{SE}, \mathrm{n}=3$

in sinking colonies, but in both cases the mean ratio was $50 \%$ or less of the maximum ratio (Fig. 5). As previously shown (Villareal \& Carpenter 2003), sinking colonies in the Gulf of Mexico had significantly higher $(p<0.0001) \mathrm{N}$ :P ratios compared to floaters, ranging from 63 to 100 and averaging about 90. The overall 
average of the samples collected (both floating and sinking colonies) was 68.4. The N:P ratio of colonies decreased moving offshore (Fig. 6).

The depth pattern of the N:P ratio in Trichodesmium colonies was distinct for floating and sinking colonies, and varied along the transect (Fig. 7). Except for Stn 1, floating colonies tended to have higher N:P ratios near the surface and were relatively uniform at depth. In most cases, the $\mathrm{N}: \mathrm{P}$ ratio of sinking colonies far exceeded that of rising colonies collected from the same depth. There was, however, no clear pattern with depth for sinking colonies.

Biomass N:P ratios of samples of Trichodesmium collected in the Pacific in 2002 and 2003 averaged 36.2 and 40.1 , and were not significantly different ( $p>0.05)$ from each other. Katygnemene collected in 2002 had an average biomass $\mathrm{N}: \mathrm{P}$ of 33.9 and was not significantly different $(p>0.05)$ from the Trichodesmium collected that same year. Neither Trichodesmium nor Katygnemene biomass N:P ratios showed correlation to $\mathrm{PO}_{4}{ }^{3-}$ concentrations (Fig. 8).

\section{DISCUSSION}

Both laboratory cultures and field populations of Trichodesmium exhibited a broad range of N:P ratios, depending on their nutrient environment. Furthermore, our data suggest that the biomass N:P ratio of Trichodesmium, and other diazotrophs such as Katygnemene, respond to, and may be a useful diagnostic of, phosphorus limitation.

Laboratory cultures show a distinct response in biomass $\mathrm{N}$ :P ratios to limiting phosphorus and alter their

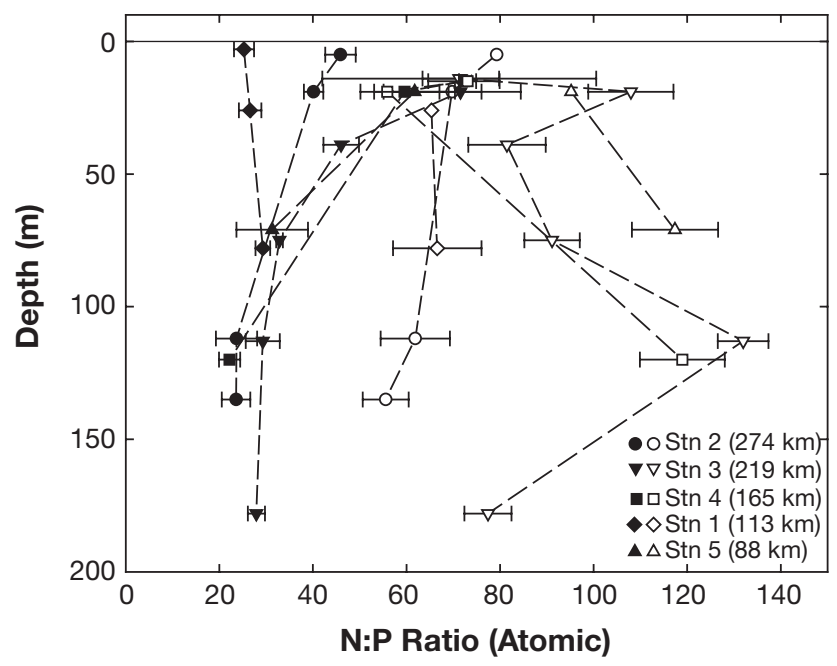

Fig. 7. Trichodesmium spp.. Depth profiles of N:P ratios for colonies (Gulf of Mexico). Distance offshore for each station given in parentheses. Open symbols = sinking, closed symbols $=$ floating. Error bars are $\pm \mathrm{SE}$

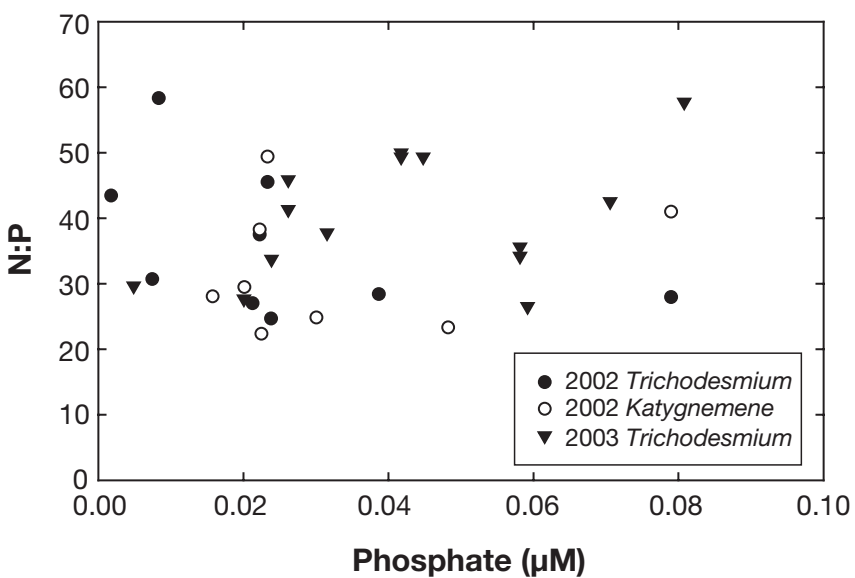

Fig. 8. N:P ratios of Trichodesmium spp. colonies in the North Pacific subtropical gyre in 2002, 2003, and Katygnemene in 2002 compared to $\mathrm{PO}_{4}{ }^{3-}$ concentrations

biomass N:P substantially before starvation is manifested in cell biomass, chlorophyll, or $\mathrm{N}_{2}$ fixation rates as occurs later in the growth curve. The lower biomass in low phosphate medium compared to high phosphate medium further confirms that cells were phosphate depleted in the low phosphate experiments. While cultures grown with low phosphate have N:P ratios that were initially similar to those cultures grown on higher phosphate media, the divergence is marked and large once phosphate levels are depleted. In contrast, the $\mathrm{N}: \mathrm{P}$ ratio of each culture grown on standard YBC II media remained relatively constant and lower than the Redfield ratio, indicating phosphate sufficiency throughout the growth curves.

Phosphate concentrations in the filtrate were inversely related to the trend in the biomass $\mathrm{N}$ :P ratios, as would be expected in phosphate-depleted cultures (Fig. 9). In YBC II media cultures, the ambient dissolved phosphate levels remained relatively constant throughout the duration of the growth curve, dropping to no more than $40 \%$ of the initial concentration by the

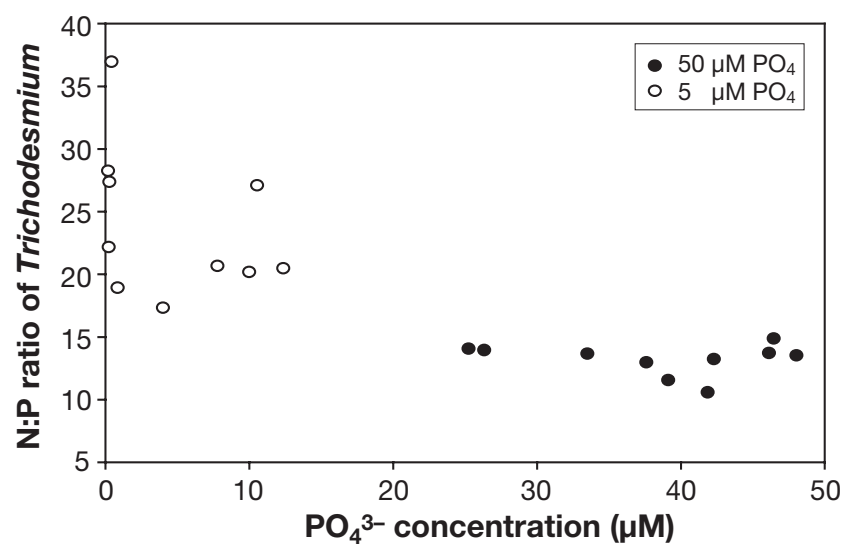

Fig. 9. Phosphate concentration vs. N:P ratio in culture Expt 2 
final time point, indicating that phosphorus limitation was not reached. In contrast, the low-phosphate grown cultures had a much more significant decrease in ambient phosphate over time as the limited nutrient supply was depleted.

There were, however, differences in the 2 experiments. In Expt 1, the growth rate of Trichodesmium was apparently not limited by $\mathrm{P}$ over the time course, but large changes in biomass N:P ratio were seen. Thus, the biomass N:P ratio is very sensitive, and increases when Trichodesmium reaches $\mathrm{P}$ depletion. The growth rate was also the same in the 2 treatments in the beginning of Expt 2. However, towards the end of this experiment, biomass in the low phosphate cultures dropped off sharply. Here, biomass N:P levels did not increase as much as in Expt 1, yet biomass became limited in the end. Different pre-treatment (P replete for both in Expt 1 but different conditions in Expt 2 with each treatment being raised under the respective experimental regime of either high or low phosphate) accounts for the initial higher biomass $\mathrm{N}$ :P ratio seen in the low phosphate treatment compared to the high phosphate treatment in Expt 2. The differences in the growth curves may also be accounted for by the differences in pre-conditioning. In Expt 1, the sustained growth in the low phosphate treatment while biomass $\mathrm{N}: \mathrm{P}$ increased may have resulted from the mobilization of P reserves (generally as polyphosphate granules in Trichodesmium) or perhaps as phosphates (Dyhrman et al. 2006). It is likely that initial inoculum in the low phosphate treatment in Expt 2 would have had far lower P reserves with the result that biomass increase ceased at an earlier point in the time course.

The culture experiments described here show that the biomass N:P ratio in Trichodesmium responds strongly to $\mathrm{P}$ availability and may have utility as a field indicator of P stress. We do not suggest that it is possible to relate the actual numbers from the cultures to the field, however. Batch culture experiments are similar to what might be seen in a bloom as cells undergo progressive nutrient exhaustion, and as the conditions are highly controlled, we know that the observed result is from the depletion of $\mathrm{P}$ in the media. When Trichodesmium is encountered in the field, its nutritional history is not known and growth could be balanced (which was not the case in the culture experiments). However, we know from the controlled culture experiments that the trend of higher biomass N:P ratios comes from $\mathrm{P}$ starvation. It is important to note that it does not necessarily indicate that $\mathrm{P}$ is the limiting nutrient to growth of Trichodesmium in the field as other P sources may be available (Sohm \& Capone 2006).

Substantial variation was noted in Trichodesmium biomass N:P ratios both within and among the field sites (Table 1). Highest biomass N:P ratios in Trichodesmium biomass were found in the Gulf of Mexico samples. The sinking colonies had the highest biomass $\mathrm{N}: \mathrm{P}$ overall, and the average biomass N:P of all samples combined was higher than at any other site. The $\mathrm{N}$ :P loading ratio in the Gulf from the Mississippi River is generally large and in excess of Redfield (Turner et al. 2003 and thus may explain the high biomass N:P seen there). Very high ratios were also found in the North Atlantic, with a trend towards higher N:P ratios on the western side of the basin. Phosphate in surface waters of the North Atlantic was below detection limits at all stations. The lowest average biomass N:P ratios of colonies were found on the North Australian transect, with intermediate values in the North Pacific samples. In the 2 Pacific samplings (RV 'Maurice Ewing' and RV 'Roger Revelle') we often encountered T. erythraeum rather T. thiebautii which is more common in the North Atlantic. T. thiebautii has a larger cellular diameter (typically about $7 \mu \mathrm{m}$ ) compared to $T$. erythraeum (typically about $3 \mu \mathrm{m}$ ) and tends to form larger colonies (100 to 200 vs. 50 to 150 trichomes per colony, respectively; Carpenter 1983b, Carpenter et al. 2004). Hence the lower per colony $\mathrm{N}$ and $\mathrm{P}$ content is not surprising.

Table 1. Summary of N:P ratios and PON and POP content of colonies (col) for the various cruises. na = not available; $\mathrm{n} / \mathrm{a}=$ not applicable

\begin{tabular}{|c|c|c|c|c|c|c|c|c|c|c|}
\hline Cruise & Year & Sample & $\begin{array}{l}\text { No. of } \\
\text { stations }\end{array}$ & $\begin{array}{c}\text { Average } \\
\mathrm{N}: \mathrm{P}\end{array}$ & $\mathrm{SE}$ & $\begin{array}{c}\mathrm{nmol} N \\
\mathrm{col}\end{array}$ & $\mathrm{SE}$ & $\begin{array}{c}\mathrm{nmol} P \\
\mathrm{col}\end{array}$ & $\mathrm{SE}$ & $\begin{array}{c}\mathrm{N}: \mathrm{P} \\
\text { from Avg }\end{array}$ \\
\hline RV 'Maurice Ewing' & 1999 & Colonies & 16 & 22.4 & 2.20 & 75.3 & 0.02 & 3.24 & 0.00 & 23.3 \\
\hline RV 'Longhorn' & $\begin{array}{l}2000 \\
2000\end{array}$ & $\begin{array}{l}\text { Sinkers } \\
\text { Floaters }\end{array}$ & $\begin{array}{l}7 \\
8\end{array}$ & $\begin{array}{l}89.5 \\
49.9\end{array}$ & $\begin{array}{l}6.94 \\
4.90\end{array}$ & $\begin{array}{l}108.5 \\
121.2\end{array}$ & $\begin{array}{l}17.7 \\
21.6\end{array}$ & $\begin{array}{l}1.29 \\
2.59\end{array}$ & $\begin{array}{l}0.19 \\
0.30\end{array}$ & $\begin{array}{l}84.1 \\
46.8\end{array}$ \\
\hline RV 'Seward Johnson' & 2000 & Colonies & 9 & 43.5 & 4.08 & na & na & na & na & \\
\hline RV 'Roger Revelle' & 2003 & Colonies & 14 & 40.1 & 2.53 & 28.7 & 2.08 & 0.742 & 0.042 & 38.6 \\
\hline RV ‘Kilo Moana' & 2002 & $\begin{array}{l}\text { Colonies } \\
\text { Free trichomes } \\
\text { Katygnemene }\end{array}$ & $\begin{array}{c}10 \\
10 \\
8\end{array}$ & $\begin{array}{l}36.2 \\
33.9 \\
32.1\end{array}$ & $\begin{array}{l}3.35 \\
3.27 \\
3.44\end{array}$ & $\begin{array}{l}83.1 \\
\mathrm{n} / \mathrm{a} \\
\mathrm{n} / \mathrm{a}\end{array}$ & $\begin{array}{c}21.8 \\
\mathrm{n} / \mathrm{a} \\
\mathrm{n} / \mathrm{a}\end{array}$ & $\begin{array}{l}2.06 \\
\mathrm{n} / \mathrm{a} \\
\mathrm{n} / \mathrm{a}\end{array}$ & $\begin{array}{c}0.33 \\
\mathrm{n} / \mathrm{a} \\
\mathrm{n} / \mathrm{a}\end{array}$ & 40.3 \\
\hline
\end{tabular}


The Trichodesmium IMS 101 culture is putatively $T$. erythraeum (Orcutt et al. 2002). For comparison with the field studies, and assuming 150 trichomes per colony, the $\mathrm{P}$ content of the high phosphate culture in the second experiment averaged $3.1 \pm 0.22 \mu$ mol P per colony, and $27 \pm 3.52 \mu \mathrm{mol} \mathrm{N}$ per colony while the low phosphate culture averaged $2.5 \pm 0.16 \mu \mathrm{mol} \mathrm{P}$ per colony and $10.2 \pm 3.21 \mu \mathrm{mol} N$ per colony. The N:P ratios varied as described in Figs. 2 \& 3 from near-Redfield to approximately 125 under severe P depletion.

Recent geochemical (Wu et al. 2000) and biological (Cotner et al. 1997, Sañudo-Wilhelmy et al. 2001, Dyhrman et al. 2002, Mulholland et al. 2002, Ammerman et al. 2003) evidence from the North Atlantic suggest that phosphorus may be in much shorter supply, relative to $\mathrm{Fe}$, for surface diazotrophs. In addition, the phosphocline is generally deeper than the nitracline in the Sargasso Sea (Michaels et al. 1994, Wu et al. 2000). In the North Atlantic Ocean and Sargasso Sea, a highly oligotrophic basin, our research provides further evidence for severe phosphate depletion and suggests that phosphorus levels may be sufficiently low to exercise control on diazotrophs. The high Trichodesmium biomass N:P ratios and low phosphate concentrations in the Gulf of Mexico also suggest a potential for severe P limitation.

Across the northern Australian coast, throughout the Arafura, Timor, and Coral Seas, Trichodesmium biomass N:P ratios were generally lower, ranging from 11 to 47 , with an average much closer to the Redfield ratio at 22. This suggests a higher availability of phosphorus, possibly a result of the relatively shallow sediments or proximal terrestrial influences, or both. Indeed, phosphate concentrations, while low, were usually measurable, and in the surface appeared to be generally in excess of nitrate (low soluble inorganic $\mathrm{N}: \mathrm{P})$. Compared with results from the culture experiments and the North Atlantic and Gulf of Mexico transects, it appears that Trichodesmium in the waters north of Australia are not highly P limited. Indeed, at most sites, the N:P of DIN to DIP was lower than the Redfield ratio (data not shown), suggesting $\mathrm{P}$ sufficiency there.

In the NPSG, N:P ratios of Trichodesmium biomass were also closer to Redfield than in the apparently Plimited Gulf of Mexico and western North Atlantic (generally <50 compared to $>50$ ). In addition, the ratios were consistent for 2 consecutive years. Katygnemene, a diazotroph very closely related to Trichodesmium, exhibited the same N:P ratio, as the Trichodesmium collected that same year, suggesting they do not respond differently to phosphate concentrations. The relatively lower $\mathrm{N}: \mathrm{P}$ ratios found in the Pacific, and the failure of ratios to correlate with $\mathrm{PO}_{4}{ }^{3-}$ concentrations, implies that Trichodesmium is not P- limited in the NPSG. However, colonies could be Pstressed at certain locations, as biomass N:P was $>50$ for some stations.

Comparing the values for $\mathrm{N}: \mathrm{P}$ in the field with those found in culture experiments, it appears that Trichodesmium in all basins are dealing with some level of P deficiency, except for certain areas north of Australia. Ratios below Redfield are likely caused by luxury consumption and storage of phosphate. It remains to be seen at what $\mathrm{N}: \mathrm{P}$ ratio these stores run out and colonies truly become P-limited. Kustka et al. (2003) suggest that an N:P ratio of about 40 is the critical ratio for P limitation, based on a comparison of $\mathrm{N}_{2}$ fixation rates to N:P ratios. Our present findings roughly agree with their study.

While several studies have observed field populations of Trichodesmium with respect to molar biomass $\mathrm{N}: \mathrm{P}$ ratio, the data are relatively limited in space and time. Mague et al. (1977) reported an N:P ratio of 20:1 for Trichodesmium colonies collected at one station north of the Hawaiian Islands. Letelier \& Karl (1996) reported molar N:P ratios for free trichomes of 52 and 45 for May 1990 and October 1991, respectively, and of $42 \pm 6.15$ (SD) for colonies from Stn ALOHA. Letelier \& Karl (1998) examined the N:P ratio of sinking and rising colonies collected from 5 and $100 \mathrm{~m}$. Near surface colonies averaged an N:P ratio of about 43 regardless of buoyancy, while rising colonies from depth had a lower, although not significantly different, N:P ratio $(\sim 34)$ than sinking colonies $(\sim 45)$. These values fall in the mid-range relative to our Gulf of Mexico and Atlantic samples. Sañudo-Wilhelmy et al. (2001) found a relatively low $\mathrm{N}: \mathrm{P}$ ratio $(\sim 18)$ in their subtropical North Atlantic transect between 10 and $16^{\circ} \mathrm{N}$, with higher values ( 50) further south between 0 and $6^{\circ} \mathrm{N}$. Karl et al. (1992) reported very high biomass N:P ratios (125:1) in surface particulates after a Trichodesmium bloom event, providing further evidence of a very flexible cell quota for Trichodesmium. White et al. (pers. comm.) have also found wide variability in the N:P ratios of Trichodesmium continuous cultures as a function of $\mathrm{P}$ availability.

Recently, Sañudo-Wilhelmy et al. (2004) reported that a significant portion of cellular $\mathrm{P}$ is adsorbed to the cell surface of Trichodesmium colonies. The extent of $\mathrm{PO}_{4}{ }^{3-}$ adsorption, which is variable, has implications for the use of bulk N:P as an indicator of $\mathrm{P}$ stress. High concentrations of adsorption of $\mathrm{PO}_{4}{ }^{3-}$ relative to that bound organically would lower the bulk $\mathrm{N}: \mathrm{P}$ ratio relative to the actual PON:POP. We did not correct for this extracellular $\mathrm{P}$ in our measurements, and thus the intracellular $\mathrm{N}: \mathrm{P}$ ratio is likely greater than the numbers reported here. While extracellular phosphorus is not part of the so-called 'biological pool', a recent experiment suggests Trichodesmium 
can internalize the extracellular pool at a rate of approximately $25 \% \mathrm{~d}^{-1}$, and thus it is important to cells (Fu et al. 2005).

Plasticity in $\mathrm{N}: \mathrm{P}$ ratios is not restricted to diazotrophs: other marine cyanobacteria also exhibit considerable placticity in their cellular N:P ratios. Synechococcus and Prochlorococcus strains showed biomass N:P ratios of 21 to 33 under nutrient-replete conditions and 59 to 109 under P limitation (Bertilsson et al. 2003). A separate study found ranges of 15 to 24 for Prochlorococcus and 7 to 36 for Synechococcus (Heldal et al. 2003). Such plasticity is also commonly noted in eukaryotes. For example, Goldman et al. (1979) reported an N:P ratio range of 15:1 to 100:1 for Monochrysis lutheri. Karl et al. (2001) found considerable seasonal and interannual variability in $\mathrm{N}: \mathrm{P}$ ratios of both soluble and particulate material at Stn ALOHA in the NPSG. This included a secular trend of increasing N:P ratio in the particulate pool over the 9 yr observation period.

Understanding the cellular stoichiometry of marine plankton, and in particular diazotrophs, has important implications in a number of arenas (Mahaffey et al. 2005). In a geochemical analysis of nutrient fields in the North Atlantic, Gruber \& Sarmiento (1997) integrated the excess $\mathrm{N}$ accumulating along isopycnals, and derived an estimate for the amount of $\mathrm{N}_{2}$ fixation needed to account for this by assuming an N:P ratio for diazotrophs well above Redfield to account for the ingrowth of the nitrate. They chose a value for Trichodesmium biomass of $125 \mathrm{~N}: 1 \mathrm{P}$, gleaned from the study by Karl et al. (1992). Gruber \& Sarmiento (1997) recognized the sensitivity of their $N^{*}$ based estimate to the N:P ratio selected. Given our evidence, a lower value may be appropriate. Using a value of 45 (rather than 125) would increase their $\mathrm{N}_{2}$ fixation estimate for the Atlantic by about $50 \%$. However, as noted by Hansell et al. (2004), large uncertainties exist in the $\mathrm{N}$ fixation estimates based on $N^{*}$. Hansell et al. (2004) estimates suggest $\mathrm{N}_{2}$ fixation rates of approximately 10 to $25 \%$ of that suggested from the Gruber \& Sarmiento (1997) analysis.

As the modeling of marine systems advances and incorporates functions such as $\mathrm{N}_{2}$ fixation, knowledge of the elemental stoichiometry of diazotrophs becomes critical (Hood et al. 2000). However, most coupled biogeochemical models assume Redfield C:N:P stoichiometry, although this approach is slowly changing. Correct representation of the stoichiometry of $\mathrm{N}_{2}$ fixers is important if models are meant to be representations of the real world. Our research shows that Trichodesmium does not conform to Redfield stoichiometry with respect to its $\mathrm{N}: \mathrm{P}$ ratios and that these ratios respond to, and are indicative of, $\mathrm{P}$ limitation in this abundant and cosmopolitan diazotroph.
Acknowledgements. We thank Laura Sprague for nutrient analysis, Miles Furnas for logistic assistance during the Australian transect, Karin Bjorkman for low level phosphate data for the RV 'Roger Revelle' cruise, and the crews of the RV 'Maurice Ewing' 'Longhorn', 'Seward Johnson', 'Kilo Moana' and 'Roger Revelle' for their invaluable assistance in field collections. This is contribution no. 1340 from The University of Texas Marine Science Institute. D.G.C., J.P.M. and T.A.V. thank the Biological Oceanography Section of the Ocean Sciences Division of NSF for support of this research.

\section{LITERATURE CITED}

Ammerman JW, Hood RR, Case DA, Cotner JB (2003) Phosphorus deficiency in the Atlantic: an emerging paradigm in oceanography. EOS Trans Am Geophys Union 84:165-170

Bertilsson S, Berglund O, Karl DM, Chisholm SW (2003) Elemental composition of marine Prochlorococcus and Synechococcus: implications for the ecological stoichiometry of the sea. Limnol Oceanogr 48:1721-1731

Capone DG (1993) Determination of nitrogenase activity in aquatic samples using the acetylene reduction procedure. In: Kemp PF, Sherr BF, Sherr EB, Cole JJ (eds) Handbook of methods in aquatic microbial ecology. Lewis Press, Boca Raton, FL, p 621-631

Capone DG, Zehr J, Paerl H, Bergman B, Carpenter EJ (1997) Trichodesmium: a globally significant marine cyanobacterium. Science 276:1221-1229

Capone DG, Burns JA, Mahaffey CL, Gunderson T, Michaels AF, Montoya JP, Subramaniam A, Carpenter EJ (2005) Nitrogen fixation by Trichodesmium spp.: an important source of new nitrogen to the tropical and sub-tropical North Atlantic Ocean. Global Biogeochem Cycles 19: 10.1029/2004GB002331

Carpenter EJ (1983a) Nitrogen fixation by marine Oscillatoria (Trichodesmium) in the world's oceans. In: Carpenter EJ, Capone DG (eds) Nitrogen in the marine environment. Academic Press, New York, p 65-103

Carpenter EJ (1983b) Physiology and ecology of marine Oscillatoria (Trichodesmium). Mar Biol Lett 4:69-85

Carpenter EJ, Subramaniam A, Capone DG (2004) Biomass and primary productivity of the cyanobacterium, Trichodesmium spp., in the southwestern tropical N Atlantic Ocean. Deep-Sea Res Part I 51:173-203

Chen YB, Zehr JP, Mellon M (1996) Growth and nitrogen fixation of the diazotrophic filamentous nonheterocystous cyanobacterium Trichodesmium sp. IMS 101. J Phycol 32:916-923

Cotner JB, Ammerman JW, Peele ER, Bentzen E (1997) Phosphorus-limited bacterioplankton growth in the Sargasso sea. Aquat Microb Ecol 13:141-149

D'Elia CF, Steudler PA, Corwin N (1977) Determination of total nitrogen in aqueous samples using persulfate digestion. Limnol Oceanogr 22:760-764

Deutsch C, Gruber N, Key R, Sarmiento J (2001) Denitrification and $\mathrm{N}_{2}$ fixation in the Pacific Ocean. Global Biogeochem Cycles 15:483-506

Dyhrman ST, Webb EA, Anderson DM, Moffett JW, Waterbury JB (2002) Cell-specific detection of phosphorus stress in Trichodesmium from the western north Atlantic. Limnol Oceanogr 47:1832-1836

Dyhrman ST, Chappel PD, Haley ST, Moffet JW, Orchard ED, Waterbury JB, Webb EA (2006) Phosphate utilization by the globally important marine diazotroph Trichodesmium. Nature 439:68-71 
Fu FX, Zhang Y, Leblanc K, Sanudo-Wilhelmy SA, Hutchins DA (2005) The biological and biochemical consequences of phosphate scavenging onto phytoplankton cell surfaces. Limnol Oceanogr 50(5):1459-1472

Goldman JC, McCarthy JJ, Peavey DG (1979) Growth rate influence on the chemical composition of phytoplankton in oceanic waters. Nature 279:210-215

Gruber N, Sarmiento J (1997) Global patterns of marine nitrogen fixation and denitrification. Global Biogeochem Cycles 11:235-266

Hansell D, Bates N, Olson D (2004) Excess nitrate and nitrogen fixation in the North Atlantic Ocean. Mar Chem 84:243-265

Heldal M, Scanlan DJ, Norland S, Thingstad F, Mann NH (2003) Elemental composition of single cells of various strains of marine Prochlorococcus and Synechococcus using X-ray microanalysis. Limnol Oceanogr 48: 1732-1743

Hood RR, Michaels AM, Capone DG (2000) Answers sought to the enigma of marine nitrogen fixation. EOS Trans Am Geophys Union 81:133, 138-139

Karl DM, Letelier R, Hebel DV, Bird DF, Winn CD (1992) Trichodesmium blooms and new nitrogen in the north Pacific gyre. In: Carpenter EJ, Capone DG, Rueter JG (eds) Marine pelagic cyanobacteria: Trichodesmium and other diazotrophs. Kluwer Academic, Dordrecht, p 219-237

Karl DM, Bjorkman KM, Dore JE, Fujieki L, Hebel DV, Houlihan T, Letelier RM, Tupas LM (2001) Ecological nitrogento-phosphorus stoichiometry at station ALOHA. Deep-Sea Res Part II 48:1529-1566

Karl DM, Michaels A, Bergman B, Capone DG and 6 others (2002) Dinitrogen fixation in the world's oceans. Biogeochemistry 57:47-98

Kustka AB, Sanudo-Wilhelmy SA, Carpenter EJ, Capone D, Burns J, Sunda WG (2003) Iron requirements for dinitrogen- and ammonium-supported growth in cultures of Trichodesmium (IMS 101): comparison with nitrogen fixation rates and iron: carbon ratios of field populations. Limnol Oceanogr 48:1869-1884

Letelier RM, Karl DM (1996) Role of Trichodesmium spp. in the productivity of the subtropical north Pacific Ocean. Mar Ecol Prog Ser 133:263-273

Letelier RM, Karl DM (1998) Trichodesmium spp. physiology and nutrient fluxes in the North Pacific subtropical gyre. Aquat Microb Ecol 15:265-276

MacKinney G (1941) Absorption of light by chlorophyll solutions. J Biol Chem 140:315:322

Mague TH (1977) Ecological aspects of nitrogen fixation by blue-green algae. In: Hardy RWF, Gibson AH (eds) A treatise on dinitrogen fixation. Section IV: Agronomy and ecology. John Wiley \& Sons, New York, p 85-140

Mague TH, Mague FC, Holm-Hansen O (1977) Physiology and chemical composition of nitrogen-fixing phyto-

Editorial responsibility: Jed Fuhrman,

Los Angeles, California, USA plankton in the central north Pacific Ocean. Mar Biol 41:212-227

Mahaffey C, Michaels A, Capone DG (2005) The conundrum of marine nitrogen fixation. Am J Sci 305:546-595

McCarthy JJ, Carpenter EJ (1979) Oscillatoria (Trichodesmium) thiebautii (Cyanophyta) in the central north Atl Ocean J Phycol 15:75-82

Michaels AF, Knap AH, Dow RL, Gundersen K and 8 others (1994) Seasonal patterns of ocean biogeochemistry at the United-States JGOFS Bermuda Atlantic Time-Series Study Site. Deep-Sea Res Part I 41:1013-1038

Michaels AF, Olson D, Sarmiento JL, Ammerman JW and 5 others (1996) Inputs, losses and transformations of nitrogen and phosphorus in the pelagic north Atlantic Ocean. Biogeochemistry 35:181-226

Mulholland M, Capone D (1999) Nitrogen fixation, uptake and metabolism in natural and cultured populations of Trichodesmium spp. Mar Ecol Prog Ser 188:33-49

Mulholland MR, Capone DG (2001) Stoichiometry of nitrogen and carbon utilization in cultured populations of Trichodesmium IMS 101. Limnol Oceanogr 46:436-443

Mulholland MR, Floge S, Carpenter EJ, Capone DG (2002) Phosphorus dynamics in cultures and natural populations of Trichodesmium spp. Mar Ecol Prog Ser 45:45-55

Orcutt KM, Rasmussen U, Webb EA, Waterbury JB, Gundersen K, Bergman B (2002) Characterization of Trichodesmium spp. by genetic techniques. Appl Environ Microbiol 68:2236-2245

Raimbault P, Diaz F, Pouvesle W, Boudjellal B (1999) Simultaneous detrmination of particulate organic carbon, nitrogen and phosphorus collected on filters, using a semiautomated wet-oxidation method. Mar Ecol Prog Ser 180:289-295

Sañudo-Wilhelmy SA, Kustka AB, Gobler CJ, Hutchins DA and 6 others (2001) Phosphorus limitation of nitrogen fixation by Trichodesmium in the central Atlantic Ocean. Nature 411:66-69

Sañudo-Wilhelmy SA, Tovar-Sanchez A, Fu FX, Capone DG, Carpenter EJ, Hutchins DA (2004) The impact of surfaceadsorbed phosphorus on hytoplankton Redfield stoichiometry. Nature 432:897-901

Sohm JA, Capone Dg (2006) Phosphorus dynamics of the tropical and subtropical north Atlantic: Trchodesmium spp. versus bulk plankton. Mar Ecol Prog Ser (in press)

Turner RE, Rabelais NN, Justic D, Dortch Q (2003) Global patterns of dissolved N, P and Si in large rivers. Biogeochemistry 64:297-317

Villareal T, Carpenter EJ (2003) Buoyancy regulation and potential for vertical migration in the oceanic cyanobacterium Trichodesmium. Microb Ecol 45:1-10

Wu J, Sunda W, Boyle EA, Karl DM (2000) Phosphate depletion in the western North Atlantic Ocean. Science 289:759-762

Submitted: November 5, 2004; Accepted: December 6, 2005 Proofs received from author(s): March 9, 2006 